\title{
Article \\ Susceptibility of Fluconazole-Resistant Candida albicans to Thyme Essential Oil
}

\author{
Najla A Alshaikh and Kahkashan Perveen *(D) \\ Department of Botany and Microbiology, College of Science, King Saud University, Riyadh 11495, Saudi Arabia; \\ nalshaikh@ksu.edu.sa \\ * Correspondence: kperveen@ksu.edu.sa
}

Citation: Alshaikh, N.A.; Perveen, K. Susceptibility of FluconazoleResistant Candida albicans to Thyme Essential Oil. Microorganisms 2021, 9, 2454. https://doi.org/10.3390/ microorganisms 9122454

Academic Editors: Francesca Bugli and Maura Di Vito

Received: 5 November 2021

Accepted: 24 November 2021

Published: 28 November 2021

Publisher's Note: MDPI stays neutral with regard to jurisdictional claims in published maps and institutional affiliations.

Copyright: (c) 2021 by the authors. Licensee MDPI, Basel, Switzerland. This article is an open access article distributed under the terms and conditions of the Creative Commons Attribution (CC BY) license (https:// creativecommons.org/licenses/by/ $4.0 /)$.

\begin{abstract}
Candida spp. is the most common microbial pathogen in fungal infections. There has been a tremendous increase in cases of candidiasis, especially among critically ill non-neutropenic patients. Candida albicans' isolates were procured from the Prince Sultan Military Hospital, Riyadh, KSA. The isolates were characterized for their identification using CHROMagar, carbohydrate metabolism, germ tube formation, and RAPD-PCR techniques. The essential oil of Thymus vulgaris was obtained by hydro-distillation and characterized to decipher the major bioactive phytoconstituents. The antifungal activity of the thyme essential oil (TEO) was evaluated against fluconazole-resistant C. albicans isolates. The major phytocomponents identified by GC/MS were thymol (68.1\%) followed by $\gamma$-terpinene $(8.9 \%)$, cymol $(7.7 \%)$, caryophyllene $(1.1 \%)$, linalool $(1.4 \%)$. The TEO successfully reduced the growth of $C$. albicans isolates. At very low doses, the TEO proved to be fungi static and fungicidal. TEO also effectively inhibited the germ tube formation and budging of fungal pathogens. The time kill assays have shown that TEO was more effective against drug resistant clinical isolates than fluconazole. This study provides an array of experimental evidence regarding the therapeutic efficacy of TEO against the drug-resistant clinical isolates of C. albicans. The findings may be used in the development of a new antifungal agent accordingly.
\end{abstract}

Keywords: Candida albicans; essential oil; thyme; fluconazole resistance

\section{Introduction}

Among fungal commensal pathogens, Candida spp. is one of the major causative agents for human infections. It colonizes the mucosal surfaces of oral-pharyngeal, gastrointestinal, and urogenital tracts $[1,2]$. In the last few decades, there has been an overwhelming increase in the Candidiasis caused by Candida species. Out of different Candida species, C. albicans is the most prominent pathogen associated with serious fungal infection as it accounts for roughly $90 \%$ of the total cases [3,4]. Candidiasis is known as the most common invasive fungal infection in critically ill non-neutropenic patients [5]. Based on numerous studies conducted in the last decade for candidemia at various hospitals in Riyadh, it is obvious that $C$. albicans is the most prevalent species for such infections [1]. Moreover, other findings have also shown that $C$. albicans is the major species that causes vaginitis in Saudi Arabian women [6].

The irresponsible and abusive usage antimicrobials both in clinical and environmental settings has led to the development of the global spread of drug resistance among microbial pathogens. This has drastically reduced the therapeutic effectiveness of antimicrobial drugs and warranted a need for the search of alternative therapies to combat such infections. Essential oils have been shown to have excellent antifungal and antibacterial properties among natural products [7-10]. Many studies conducted on essential oils and natural extracts have proved that many natural products exhibit highly momentous antibiotic properties [11-13]. Essential oils derived from aromatic plants are well-known in traditional medicine as antimicrobial agents and are known for broad-spectrum activity, such as 
antifungal properties, food preservatives, inhibitors of mycotoxin production, antimycotic agents, etc. $[14,15]$. Owing to the excellent bioactivities, researchers have focused on the screening and identification of new chemical entities from natural products exhibiting excellent antimicrobial properties [16]. The known important classes of bioactive compounds for drug discovery are alkaloids, tannins, and phenolic compounds, etc. [17].

The essential oil of thyme (Thymus spp.) has antiseptic, bronchiolytic, antispasmodic, and antimicrobial qualities, making it a popular medical plant and food preservative [18]. Thyme's medicinal potential is based on its flavonoids, thymol, eugenol, aliphatic phenols, as well as saponins, luteolin, and tetramethoxylated flavones [19]. Several investigations have indicated that thyme essential oil has antimicrobial properties, with phenols content being the most active. Thymus oils containing thymol and carvacrol have been of significant interest for some time due to the limited occurrence of these phenols in nature $[13,20]$ Kowalczyk [21] recently stated that widespread use of thymol and thyme essential oil in the healthcare industry is highly promising, but that more study and analysis is needed. In this study, thyme essential oil (TEO) was isolated using hydro-distillation process and then tested against the clinical drug resistant $C$. albicans spp. isolates.

\section{Materials and Methods}

\subsection{Collection and Characterization of Candida albicans}

A total of 120 Candida species were procured from Prince Sultan Military Hospital, Riyadh, KSA. Based on the information about the source of isolation, the Candida isolates were divided into two groups: isolates from blood and isolates from vaginal culture. The fungal isolates were preliminary identified on the basis of microscopic and macroscopic characteristics by culturing on Sabouraud Dextrose Agar (SDA) medium (Merck, Darmstadt, Germany). These isolates were characterized based on CHROMagar, germ tube development, carbohydrate metabolism, and RAPD-PCR technique.

\subsubsection{Identification of Candida sp. by CHROMagar}

The preliminary identification of yeast was done by growing the cultures on differential isolation CHROMagar medium (Paris, France). This growth medium facilitates the presumptive identification of clinical Candida species [22].

\subsubsection{Germ Tube Test for the Identification of Candida albicans}

The isolated colonies were inoculated in horse serum and then incubated at $37{ }^{\circ} \mathrm{C}$. Wet mount was prepared from inoculated horse serum and examined microscopically for production of germ tubes after 2-3 h of incubation [23].

\subsubsection{API 20c Aux System for C. albicans Identification}

The strains of C. albicans were further identified by commercially available API 20c aux System for yeasts (BioMerieux, Marcy L'Etoile, France). Samples were prepared and loaded into microtubes as per the instruction of the manufacturer, followed by $48-72 \mathrm{~h}$ incubation at $29^{\circ} \mathrm{C}$. Turbidity more than the control cupel indicated a positive result [24].

\subsubsection{Differentiation between C. albicans Isolates by RAPD-PCR Technique}

DNA from Candida samples were extracted using standard procedure [25]. The molecular typing of Candida spp. was carried out by RAPD-PCR using Ready-To-Go/RAPD analysis beads kit (GE Healthcare, Manufacturer, UK). C. albicans (ATCC 10231) was taken as positive control. The details of primers used is listed below. The amplification reaction was performed in a final volume of $25 \mu \mathrm{L}$ containing $1 \mu \mathrm{L}$ extracted genomic DNA (about $20 \mathrm{ng}), 25$ pmol single RAPD primer, and distilled water. The contents were mixed gently by vortexing. PCR was performed, carried out in a PTC0200 thermal cycler (Bio-Rad, Hercules, CA, USA). The temperature profile was: 1 cycle of $5 \mathrm{~min}$ at $95^{\circ} \mathrm{C}$, followed by 45 cycles of $1 \mathrm{~min}$ at $95^{\circ} \mathrm{C}, 1 \mathrm{~min}$ at $36^{\circ} \mathrm{C}$, and $2 \mathrm{~min}$ at $72{ }^{\circ} \mathrm{C}$. The amplification products were loaded onto $2 \%$ agarose gel and run in TBE buffer $(90 \mathrm{mM}$ boric acid, $90 \mathrm{mM}$ Tris, and $2 \mathrm{mM}$ EDTA, 
$\mathrm{pH} 8.3$ ) at $120 \mathrm{~V}$ for $2.5 \mathrm{~h}$. The products were detected by staining with ethidium bromide $(0.5 \mu \mathrm{g} / \mathrm{mL})$ and then visualized under UV light and photographed (Molecular Imager Gel Doc, Bio-Rad, Hercules, CA, USA). The following primers were used:

RSD11-(5'GCATATCAATAAGCGGAGGAAAAG-3'), OPG 14-(5'-GGATGAGACC-3'), RSD12-(5' GGTCCGTGTTTCAAGACG-3'), and OPG 17-(5'-ACGACCGACA-3').

\subsubsection{Fluconazole Susceptibility Test}

The susceptibility of C. albicans were tested by E-test as instructed by the manufacturer (AB Biodisk North America Inc., Rodlphe St Durham, NC, USA). For the determination of minimum inhibitory concentration (MIC) of fluconazole, the fungal strains were grown overnight in the presence of varying concentrations $(0-128 \mu \mathrm{g} / \mathrm{mL})$ of fluconazole in Sabouraud Dextrose Broth (SDB) medium ((Merck, Darmstadt, Germany). and checked for visible growth (turbidity). The growth was further verified by spotting the cultures from broth onto Sabouraud agar plates.

\subsection{Plant Material Collection and Extraction of Thyme Essential Oil (TEO)}

The whole aerial part of the Thyme plant (Thymus vulgaris) was collected from a local market in Riyadh, Saudi Arabia. The identity of the plant was confirmed by the taxonomist, Prof. Najat Bukhari, Department of Botany and Microbiology, King Saud University with the voucher (P/M/014). Selection of the medicinal plant was based on ethnopharmacological (traditional) usage for the treatment of diseases in Saudi Arabia.

The extraction of essential oil was performed by adding $250 \mathrm{~g}$ of the aerial plant part in $200 \mathrm{~mL}$ distilled water and heating for $3 \mathrm{~h}$ at $100{ }^{\circ} \mathrm{C}$ using a Clevenger type apparatus [26]. The TEO vapours were condensed at $8{ }^{\circ} \mathrm{C}$ and collected in glass bottles. The TEO was then dried over anhydrous sodium sulphate and filtered. The TEO was stored at $4{ }^{\circ} \mathrm{C}$ in sealed brown vials until use. In this study, $2 \mathrm{~kg}$ plant material was used for extraction.

\subsection{Gas Chromatography/Mass Spectrometry (GC/MS) Analysis of Thyme Essential Oil (TEO)}

The phytochemical components of TEO was identified using Perkin Elmer (Clarus 500, Walthman, MA, USA) gas chromatograph (GC) equipped with flame ionization detector (FID) and DB-5 capillary silica column. The initial oven temperature was set to $40{ }^{\circ} \mathrm{C}$ for $1.08 \mathrm{~min}$ and then increased to $240{ }^{\circ} \mathrm{C}$ at the rate of $3{ }^{\circ} \mathrm{C} / \mathrm{min}$. The details of operating conditions are as follows: carrier gas; helium with a flow rate of $1.0 \mathrm{~mL} / \mathrm{min}$; injector and detector temperature: 250 and $300{ }^{\circ} \mathrm{C}$, respectively; split ratio: 1:20. The interface temperature was $280{ }^{\circ} \mathrm{C}$. The mass range $(\mathrm{m} / \mathrm{z})$ of recorded spectra was 35-375 amu. The mass spectra were taken at $70 \mathrm{Ev}$, whereas a thermo quest $2000 \mathrm{GC}$ coupled with thermo fining, mass system and a DB-5 capillary column $(30 \mathrm{~m} \times 0.25 \mathrm{~mm} ; 0.25 \mu \mathrm{m}$ film thickness) was used. The rest of the operating systems were the same as for GC analysis. The compounds of the TEO were identified by comparing the hits of mass spectra with the MS computer library (NIST). The retention indices were calculated using a homologous series of n-alkanes (C6-C28).

\subsection{Antifungal Activity of Thyme Essential Oil (TEO) against C. albicans Isolates}

The TEO was tested for its efficacy against the drug resistant isolates of C. albicans.

\subsubsection{Inhibitory Effect of TEO on C. albicans Using Disc Diffusion Assay}

The preliminary anticandidal activity of TEO was tested at varying oil concentrations $(100,30,25,20,15,10,5,3$, and $2 \% v / v)$ against 20 isolates of $C$. albicans [27]. The TEO were reconstituted in 1\% Tween-20 to enhance the oil solubility. A $100 \mu \mathrm{L}$ inoculum was taken from the log phase and spread on SDA plates. Sterile discs of $5 \mathrm{~mm}$ diameter were loaded with $10 \mu \mathrm{L}$ of each concentration of TEO and then placed on SDA plates. Fluconazole E-test strip was used as positive control and 1\% Tween-20 were taken as negative control. The plates were left in laminar flow for $30 \mathrm{~min}$ to allow the diffusion of oil. The plates were 
incubated for $48 \mathrm{~h}$ at $37^{\circ} \mathrm{C}$. On completion of incubation, the diameter of the inhibition zone was recorded.

\subsubsection{Determination of Minimal Inhibitory (MIC) and Fungicidal Concentration (MFC)}

The susceptibility of $C$. albicans against TEO was further tested by determining the MIC using a broth dilution assay [28]. C. albicans isolates were grown in the absence and presence of varying dilutions $(0.3,0.6,1.25,2.5,5,10,20$, and $40 \mu \mathrm{L} / \mathrm{mL})$ of TEO in $10 \mathrm{~mL}$ SDB. One hundred $\mu \mathrm{L}$ of $C$. albicans isolate $\left(\sim 1.5 \times 10^{8} \mathrm{CFU} / \mathrm{mL}\right)$ was taken as inoculum. The control group was not given any treatment and Tween-20 was used as the solvent control. The cultures were incubated for $48 \mathrm{~h}$ at $37^{\circ} \mathrm{C}$ in a shaking incubator $(200 \mathrm{rpm} / \mathrm{min})$. The microbial growth was monitored calorimetrically at $540 \mathrm{~nm}$. The lowest concentration of TEO that inhibited the fungal (no turbidity) was considered as MIC.

For the assessment of MFC, the treatment was given as mentioned in the MIC section [29]. Briefly, $100 \mu \mathrm{L}$ of culture from each treatment dose was spread onto SDA plates and incubated at $37^{\circ} \mathrm{C}$ for $48 \mathrm{~h}$. The plates were observed for visible growth. The concentration at which 3 or lesser number of colonies were observed was taken as MFC.

\subsubsection{Effect of TEO on Budding of C. albicans Isolates}

The effect of TEO on the budding of 10 C. albicans isolates was tested at their respective half inhibitory concentration (1/2 × MIC) [30]. Briefly, C. albicans isolates were cultured in the absence and presence of TEO for $24 \mathrm{~h}$ at $37^{\circ} \mathrm{C}$. The controls were also included. The fungal cells were observed under light microscope $(40 \times)$ and one hundred cells were counted in each smear for the calculation of percentage of budding cells.

\subsubsection{Effect of TEO on Germ Tubes Formation of C. albicans Isolates}

The effect of TEO on germ tubes formation of 10 strains of $C$. albicans was also tested at their respective $1 / 2 \times$ MICs. Briefly, the isolates were cultured at $1 / 2 \times \mathrm{MIC}$ of TEO for $3 \mathrm{~h}$ at $37^{\circ} \mathrm{C}$. Following incubation, 100 cells from each sample were counted using light microscope. The germ tubes were considered positive when germ tubes were seen arising from the yeast cells without a constriction at the point of their origin from the cells.

\subsubsection{Time Kill Curve Assay}

The time kill assay of $C$. albicans was performed at its respective MFCs. The culture from log phase was taken and diluted to $0.5 \mathrm{McFarland}$ turbidity $\left(\sim 1.5 \times 10^{8} \mathrm{CFU} / \mathrm{mL}\right)$ and then $0.1 \mathrm{~mL}$ of each C. albicans isolate was used as inoculum [28]. The C. albicans isolates were cultured in the presence of the respective MFCs of TEO in $10 \mathrm{~mL} \mathrm{SDB}$. Fluconazole was used as a positive control and Tween-20 was taken as solvent control. Ten $\mu \mathrm{L}$ of culture were taken at varying time intervals $(0,4,8,12,18$, and $24 \mathrm{~h})$ to make ten-fold serial dilution and $100 \mu \mathrm{L}$ from each dilution was spread on SDA plates. The plates were incubated at $37^{\circ} \mathrm{C}$ for $48 \mathrm{~h}$ and then the number of CFUs was counted.

\subsubsection{Effect of TEO on the C. albicans Ultrastructure by Scanning Electron Microscopic (SEM)}

The inhibitory effect of TEO was further validated against $C$. albicans isolate no. 10 . The isolate was grown in the absence and presence of TEO for $24 \mathrm{~h}$ at $37^{\circ} \mathrm{C}$. After incubation, the culture was taken on glass slides and fixed with $2.5 \%$ glutaraldehyde for $3 \mathrm{~h}$. The glutaraldehyde was washed thrice with sodium cacodylate solution buffer and then postfixed in osmium tetroxide for $1 \mathrm{~h}$. The samples were then dehydrated using a graded ethanol series, 25\%, 50\%, 75\%, and 100\%, each for $10 \mathrm{~min}$. The glass slides were coated with gold and observed under JSM-6380 LA field emission scanning electron microscope (JEOL, Musashino, Japan) at $20 \mathrm{KV}$. 


\section{Results}

\subsection{Candida spp. Isolates}

In this study, 20 isolates of Candida albicans were selected from the total 120 clinical isolates of Candida spp. procured from the Prince Sultan Military Hospital, Riyadh, KSA. The obtained isolates were identified and characterized based on CHROMagar, germ tube development, carbohydrate metabolism, and RAPD-PCR technique.

\subsubsection{CHROMagar Based Identification of Candida spp.}

Based on CHROMagar identification, the relative abundance of C. albicans, C. glabrata, C. tropicalis, and C. krusei was found to be $50.83,34.1,11.67$, and $3.33 \%$, respectively.

\subsubsection{Determination of Germ Tube Formation of C. albicans}

From the average of 10 isolates, $20 \%$ of vaginal isolates showed germ tube formation while $26 \%$ of blood isolates exhibited this characteristic (Figure 1).



Figure 1. Formation of C. albicans Germ tube $(\mathbf{a}, \mathbf{b})$ in horse serum incubated for $3 \mathrm{~h}$ to form a germ tube at: $100 \times$ magnification.

\subsubsection{Morphological Examination Using Microscopy}

The morphological examination of 50 isolates using microscopy showed that the fungal strains were unicellular, spherical to oval-shaped, budding yeast-like, and gram positive. C. albicans is dimorphic and changes its morphological form depending on environmental conditions. At room temperatures, the yeast form reproduces by budding, reaching a typical diameter of $8-10 \mu \mathrm{m}$. In some physiological conditions, C. albicans exhibits a hyphal form of growth called pseudohyphae, which are spherical and thick walled. This characteristic is usually produced in septulating cells. The blastospores are formed in grape-like clusters along the length of the hyphae (Figure 2). The microscopic examination showed that $C$. albicans was found to be the most frequently encountered species.
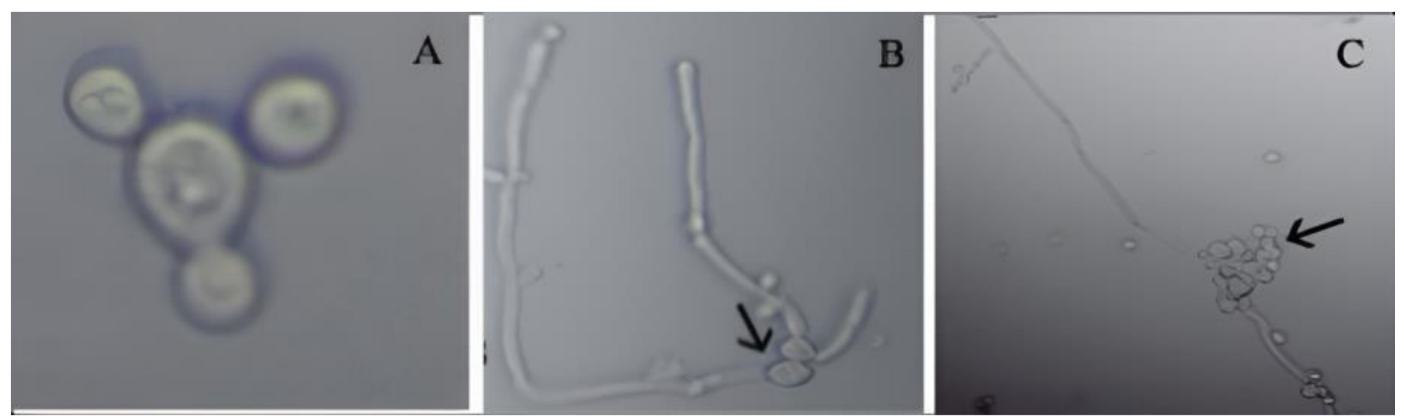

Figure 2. Various morphological forms of C. albicans at $100 \times$ magnification: (A) Budding, (B) Chlamydospores, (C) Blastospore. (B,C) Incubated in horse serum for 8 and $24 \mathrm{~h}$, respectively. 


\subsubsection{API 20c Aux Based C. albicans Identification}

In this study, 19 carbohydrate assimilation tests were performed using API 20C Aux system of yeast identification and the results were recorded after 1, 2, and 3 days. All 20 isolates were tested for carbohydrate metabolism as per the Analytical Profile Index provided in kit. Results were considered correct if results agree with the API reference identification and the profile was listed either as excellent, very good, or acceptable, as per the manufacturer instruction. The reaction of C. albicans on the API 20C Aux system ranged from $97 \%$ to $99 \%$. A total of 30 isolates of $C$. albicans gave $99 \%$ reaction. API $20 \mathrm{C}$ Aux system-based identification of 20 isolates is presented in Table 1 and these 20 strains were selected for further studies. The isolates numbered from 1 to 10 were isolated from vagina samples and isolates designated from 11 to 20 were isolated from blood samples.

Table 1. API 20C Aux results for C. albicans.

\begin{tabular}{|c|c|c|c|c|c|c|c|c|c|c|c|c|c|c|c|c|c|c|c|}
\hline \multirow{2}{*}{$\begin{array}{c}\text { Isolate } \\
\text { No. }\end{array}$} & \multicolumn{19}{|c|}{ Carbohydrate $^{1}$} \\
\hline & GLU & GLY & $2 \mathrm{KG}$ & ARA & XYL & ADO & XLT & GAL & INO & SOR & MDG & NAG & CEL & LAC & MAL & SAC & TRE & MLZ & RAF \\
\hline 1 & + & - & + & - & + & - & + & + & - & + & + & + & - & - & + & + & + & - & - \\
\hline 2 & + & - & + & - & + & - & + & + & - & + & + & + & - & - & + & + & + & - & - \\
\hline 3 & + & - & + & - & + & - & - & + & - & + & + & + & - & - & + & + & + & - & - \\
\hline 4 & + & - & + & - & + & - & + & + & - & + & + & + & - & - & + & + & + & - & - \\
\hline 5 & + & - & + & - & + & - & + & + & - & + & + & + & - & - & + & + & + & - & - \\
\hline 6 & + & - & + & - & + & - & + & + & - & + & + & + & - & - & + & + & + & - & - \\
\hline 7 & + & - & + & - & + & - & + & + & - & + & + & + & - & - & + & + & + & - & - \\
\hline 8 & + & - & + & - & + & - & + & + & - & + & + & + & - & - & + & + & + & - & - \\
\hline 9 & + & - & + & - & + & - & + & + & - & + & + & + & - & - & + & + & + & - & - \\
\hline 10 & + & - & + & - & + & - & + & + & - & + & + & + & - & - & + & + & + & - & - \\
\hline 11 & + & - & + & - & + & - & - & + & - & - & + & + & - & - & + & + & + & - & - \\
\hline 12 & + & - & + & - & + & - & + & + & - & + & + & + & - & - & + & + & + & - & - \\
\hline 13 & + & - & + & - & + & - & - & + & - & - & + & + & - & - & + & + & + & - & - \\
\hline 14 & + & - & + & - & + & - & + & + & - & + & + & + & - & - & + & + & + & - & - \\
\hline 15 & + & - & + & - & + & - & + & + & - & + & + & + & - & - & + & + & + & - & - \\
\hline 16 & + & - & + & - & + & - & + & + & - & + & + & + & - & - & + & + & + & - & - \\
\hline 17 & + & - & + & - & + & - & + & + & - & + & + & + & - & - & + & + & + & - & - \\
\hline 18 & + & - & + & - & + & - & + & + & - & + & + & + & - & - & + & + & + & - & - \\
\hline 19 & + & - & + & - & + & - & - & + & - & + & + & + & - & - & + & + & + & - & - \\
\hline 20 & + & - & + & - & + & - & - & + & - & + & + & + & - & - & + & + & + & - & - \\
\hline
\end{tabular}

${ }^{1}$ GLU: D-glucose; GLY: Glycerol; 2KG: Calcium 2-Keto-Gluconate; ARA: L-arabinose; XYL: D-xylose; ADO: Adonitol; XLT: Xylitol; GAL: D-galactose; INO: Inositol; SOR: D-sorbitol; MDG: Methyl- $\alpha$ d-Glucopyranoside; NAG: N-acetyl-glucosamine; CEL: D-cellobiose; LAC: D-lactose; MAL: D-maltose; SAC: D-saccharose (sucrose); TRE: D-trehalose; MLZ: D-melezitose; RAF: D-raffinose.

\subsubsection{Differentiation between C. albicans Isolates by RAPD-PCR Technique}

Out of the 4 primers used, two were selected, viz. OPG-17 and RSD-11, as these two primers presented reproducible DNA banding patterns for all C. albicans strains. The OPG-17 produced multiple banding patterns with fairly equal intensities and the same genetic profiles were obtained using OPG 17. On contrary, RSD 11 produced multiple banding patterns exhibiting fairly equal intensities eliciting 4 different genotypes. The RAPD profiles are shown in Figure 3. The two primers yielded RAPD profiles that ranged from 300 to 1800 base pairs (bp) for 20 clinical C. albicans isolates. In vaginal isolates (1-10), two bands of approximately $750 \mathrm{bp}$ and $450 \mathrm{bp}$ were found when amplified with OPG-17. The profile of blood isolates has only one common band with vaginal isolates at $450 \mathrm{bp}$. The value of similarity coefficient was found to be $98 \%$ and $96 \%$ using primer OPG- 17 and RSD-11, respectively (Figure 4).

\subsection{Extraction of Thyme Essential Oil (TEO)}

The extraction of TEO was done using the Clevenger type apparatus following the standard procedure as described in the European Pharmacopoeia (Council of Europe). The yield of the TEO extracted from thyme was found to be $0.85 \%$. Further, the detection of compounds present in TEO was performed using GC/MS analysis. 

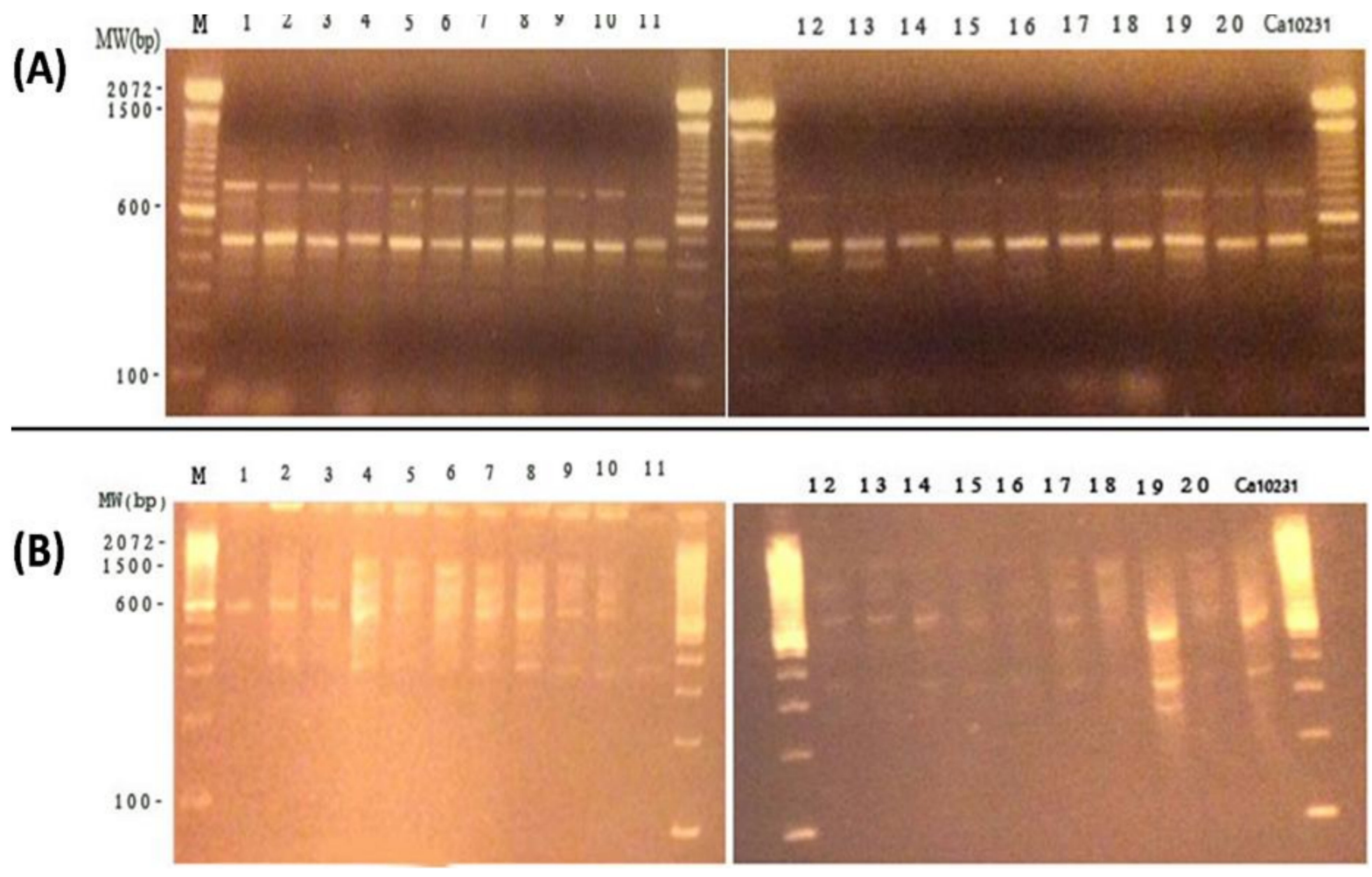

Figure 3. RAPD-PCR patterns generated by C. albicans isolates using (A) OPG 13 primer, (B) RSD 11 primer. Numbered lanes show patterns of the 20 C. albicans isolates. Ca10231: C. albicans102311. M:100 bp PCR DNA marker.

\subsection{GC/MS Analysis of Thyme Essential Oil (TEO)}

In GC/MS analysis, the identification was made by directly comparing the mass spectrum with NIST library. The GC/MS analysis of TEO showed the presence of 13 compounds (Table 2). The main constituents were found to be thymol (68.1\%) followed by $\gamma$-terpinene $(8.9 \%)$, cymol $(7.7 \%)$, caryophyllene $(1.1 \%)$, Linalool $(1.4 \%)$. Many other phytocompounds were also detected but in lower amounts.

Table 2. Chemical composition of thyme essential oil (TEO) analysed by GC/MS.

\begin{tabular}{|c|c|c|c|}
\hline No. & Compound Name & $\mathbf{R I}^{1}$ & $\%$ \\
\hline 1 & $\alpha$-Pinene & 938 & 0.49 \\
\hline 2 & 1-octen-3-ol & 981 & 1.1 \\
\hline 3 & $\beta$-myrcene & 995 & 0.4 \\
\hline 4 & 3-octanol & 998 & 0.3 \\
\hline 5 & $\alpha$-Phellandrene & 1008 & 0.2 \\
\hline 6 & $\alpha$-Terpinene & 1019 & 0.98 \\
\hline 7 & Cymol & 1026 & 7.7 \\
\hline 8 & Limonene & 1034 & 0.1 \\
\hline 9 & 1,8-Cineole & 1035 & 0.48 \\
\hline 10 & $\gamma$-Terpinene & 1065 & 8.9 \\
\hline 11 & Terpinolene & 1090 & 2.9 \\
\hline 12 & Linalool & 1105 & 1.4 \\
\hline 13 & Borneol & 1167 & 1 \\
\hline 14 & (-)4-trpineol & 1177 & 0.6 \\
\hline 15 & $\gamma$-Terpineiol & 1210 & 0.2 \\
\hline 16 & Thymol & 1301 & 68.1 \\
\hline 17 & Carvacrol & 1315 & 1.5 \\
\hline 18 & Isobornyl propionate & 1379 & 0.27 \\
\hline
\end{tabular}


Table 2. Cont.

\begin{tabular}{cccc}
\hline No. & Compound Name & RI $^{\mathbf{1}}$ & $\mathbf{\%}$ \\
\hline 19 & Caryophyllene & 1423 & 1.1 \\
20 & $\alpha$-Humulene & 1455 & 0.15 \\
21 & Germacrene-D & 1482 & 0.12 \\
22 & $\gamma$-Cadinene & 1520 & 0.18 \\
23 & Caryophyllene oxide & 1584 & 0.9 \\
24 & $\alpha$-Cadinol & 1655 & 0.13 \\
\hline \multicolumn{3}{c}{} \\
\hline
\end{tabular}

${ }^{1}$ RI, Retention Indices.


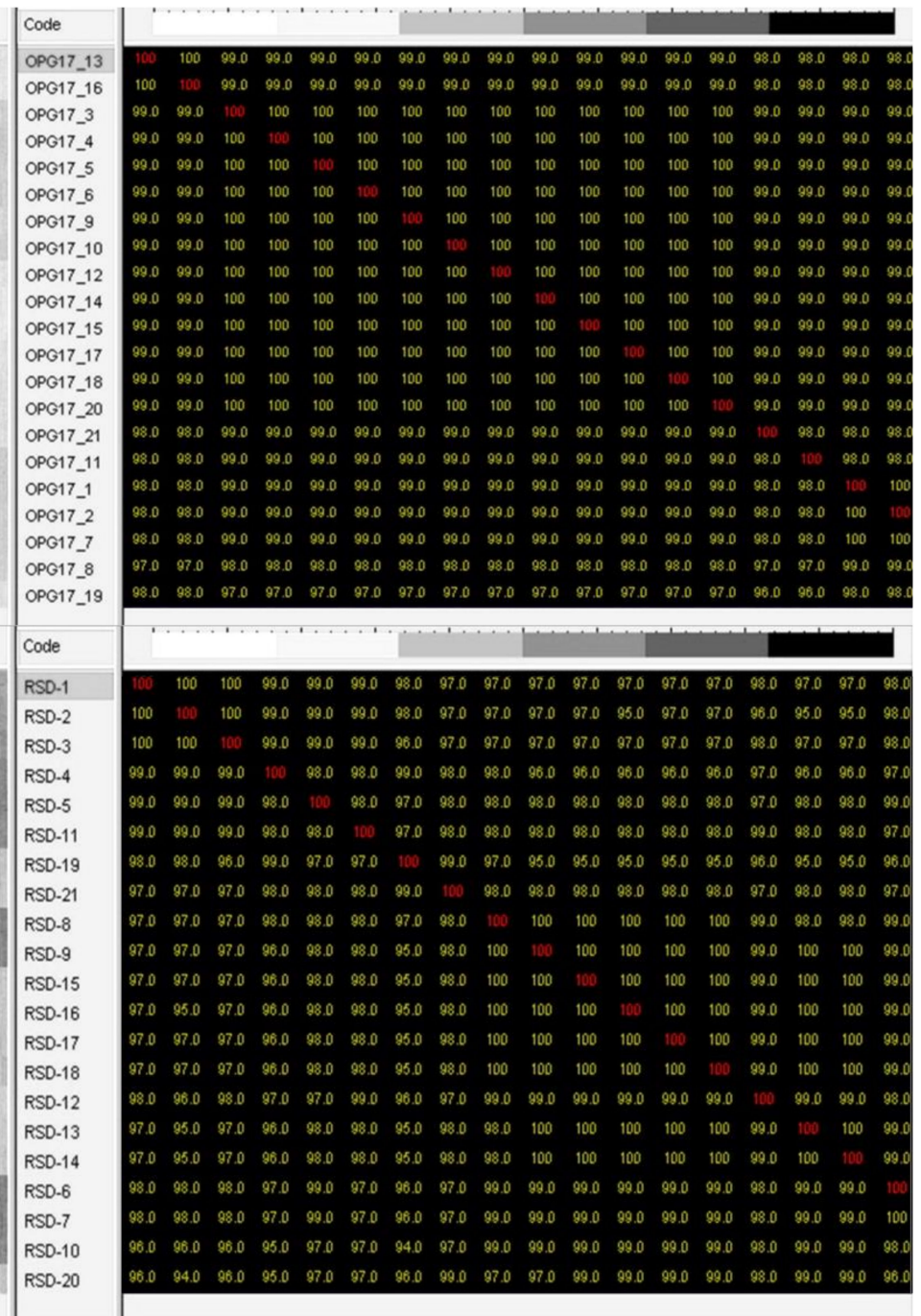

Figure 4. Dendrogram based RAPD-PCR data for C. albicans isolates from vaginal (1-10) and blood (11-20) in addition to identified isolate C. albicans102311: (A) primer OPG-17, (B) primer RSD11.

\subsection{Antifungal Activity of Thyme Essential Oil (TEO) against C. albicans Isolates}

The TEO was tested for its efficacy against the drug resistant isolates of $C$. albicans. The detailed findings are described below. 


\subsubsection{Inhibitory Effect of TEO on C. albicans Isolates Using Disc Diffusion Assay}

The preliminary antifungal effect of TEO was tested by disc diffusion assay. The TEO showed remarkable antifungal activity against all tested C. albicans isolates (Tables 3 and 4). At the lowest tested concentration (2\%), no inhibitory effect was found by disc diffusion assay. At $3 \%$ concentration, only one strain of $C$. albicans isolated from the vagina showed inhibition. At higher concentrations, a dose-dependent inhibitory effect was found against all C. albicans isolates. The average zone of inhibition against $C$. albicans vaginal isolates was recorded as $0.38 \mathrm{~cm}$ at $5 \%$ oil concentration. Likewise, average inhibition zone was $4.93 \mathrm{~cm}$ in the presence of $100 \%$ essential oil. A similar trend was observed against C. albicans blood isolates. Treatment with 5\% and 10\% TEO exhibited average inhibition zone as 1.39 and $1.79 \mathrm{~cm}$, respectively. As evident from the data, 7 vaginal isolates and $8 \mathrm{blood}$ isolates of $C$. albicans were resistant to fluconazole. Only a few strains (3 from vaginal isolates and 2 from blood isolates) were sensitive to fluconazole. Non-growth inhibition was recorded in the plates containing discs impregnated with Tween-20 (negative control). Overall, the comparison of results showed that essential thyme oil was more effective than fluconazole against the isolates.

Table 3. Zone of inhibition (cm) of C. albicans isolates from vagina at different concentrations of thyme essential oil (TEO).

\begin{tabular}{|c|c|c|c|c|c|c|c|c|c|c|c|}
\hline \multirow{2}{*}{ TEO Concentration $\%$} & \multicolumn{10}{|c|}{ Isolates } & \multirow[b]{2}{*}{ Mear } \\
\hline & 1 & 2 & 3 & 4 & 5 & 6 & 7 & 8 & 9 & 10 & \\
\hline 2 & 0.00 & 0.00 & 0.00 & 0.00 & 0.00 & 0.00 & 0.00 & 0.00 & 0.00 & 0.00 & 0.00 \\
\hline 3 & 0.77 & 0.00 & 0.00 & 0.00 & 0.00 & 0.00 & 0.00 & 0.00 & 0.00 & 0.00 & 0.17 \\
\hline 5 & 0.90 & 0.00 & 0.87 & 1.03 & 0.83 & 0.00 & 0.00 & 0.73 & 0.70 & 1.20 & 0.38 \\
\hline 10 & 1.03 & 1.93 & 2.10 & 2.13 & 1.07 & 0.87 & 0.87 & 1.10 & 1.03 & 1.77 & 0.80 \\
\hline 15 & 2.30 & 2.10 & 2.30 & 2.27 & 1.17 & 1.07 & 0.90 & 2.13 & 1.63 & 2.00 & 1.14 \\
\hline 20 & 2.50 & 2.47 & 2.40 & 2.77 & 1.17 & 1.60 & 2.17 & 2.37 & 2.00 & 2.47 & 1.69 \\
\hline 25 & 3.50 & 2.80 & 3.30 & 3.63 & 2.50 & 2.03 & 2.57 & 3.53 & 2.17 & 2.80 & 2.45 \\
\hline 30 & 3.90 & 3.00 & 3.77 & 3.80 & 4.00 & 3.30 & 2.80 & 4.03 & 3.20 & 3.83 & 3.27 \\
\hline 100 & 5.27 & 5.13 & 5.17 & 5.37 & 5.43 & 5.07 & 4.83 & 5.27 & 5.30 & 5.07 & 4.93 \\
\hline Fluco & 2.20 & 0.00 & 0.00 & 0.00 & 0.00 & 0.00 & 2.40 & 0.00 & 3.00 & 0.00 & 0.38 \\
\hline mean & 2.0 & 1.7 & 1.6 & 2.0 & 2.0 & 1.4 & 1.4 & 1.1 & 1.3 & 2.0 & \\
\hline \multicolumn{12}{|l|}{ LSD $5 \%$} \\
\hline Concentration & & & & & & 0.201 & & & & & \\
\hline Isolates & & & & & & 0.181 & & & & & \\
\hline Conc $\times$ isolates & & & & & & 0.132 & & & & & \\
\hline
\end{tabular}

Table 4. Zone of inhibition $(\mathrm{cm})$ of C. albicans isolates from blood at different concentrations of thyme essential oil (TEO).

\begin{tabular}{|c|c|c|c|c|c|c|c|c|c|c|c|}
\hline \multirow{2}{*}{ TEO Concentration $\%$} & \multicolumn{10}{|c|}{ Isolates } & \multirow[b]{2}{*}{ Mear } \\
\hline & 11 & 12 & 13 & 14 & 15 & 16 & 17 & 18 & 19 & 20 & \\
\hline 2 & 0.0 & 0.0 & 0.0 & 0.0 & 0.0 & 0.0 & 0.0 & 0.0 & 0.0 & 0.0 & 0.00 \\
\hline 3 & 1.0 & 0.0 & 0.0 & 0.0 & 0.0 & 0.0 & 0.0 & 0.0 & 0.0 & 0.7 & 0.08 \\
\hline 5 & 1.6 & 0.0 & 0.0 & 1.0 & 0.0 & 0.0 & 0.0 & 0.0 & 0.0 & 1.2 & 0.63 \\
\hline 10 & 1.3 & 0.8 & 0.0 & 1.2 & 1.6 & 0.8 & 1.0 & 0.0 & 0.0 & 1.3 & 1.39 \\
\hline 15 & 1.2 & 1.2 & 0.9 & 1.2 & 1.9 & 0.8 & 1.0 & 0.9 & 0.8 & 1.4 & 1.79 \\
\hline 20 & 2.0 & 1.9 & 1.7 & 2.1 & 2.3 & 1.2 & 1.2 & 1.0 & 1.4 & 2.0 & 2.19 \\
\hline 25 & 2.4 & 3.1 & 3.1 & 3.3 & 3.5 & 1.7 & 2.1 & 1.1 & 1.6 & 2.6 & 2.88 \\
\hline 30 & 3.5 & 3.6 & 3.3 & 3.9 & 4.1 & 3.6 & 2.8 & 2.0 & 2.5 & 3.4 & 3.56 \\
\hline $100 \%$ & 4.9 & 5.1 & 5.1 & 5.2 & 4.8 & 4.8 & 4.7 & 4.6 & 5.1 & 5.1 & 5.19 \\
\hline Fluco & 0.0 & 0.0 & 0.0 & 0.0 & 0.0 & 0.0 & 0.0 & 1.8 & 0.0 & 2.0 & 0.76 \\
\hline mean & 2.24 & 1.94 & 2.21 & 2.33 & 1.80 & 1.55 & 1.57 & 2.13 & 1.78 & 2.13 & \\
\hline \multicolumn{12}{|l|}{ LSD 5\% } \\
\hline Concentration & \multicolumn{11}{|c|}{0.0403} \\
\hline Isolates & \multicolumn{11}{|c|}{0.0419} \\
\hline Conc $\times$ isolates & \multicolumn{11}{|c|}{0.0967} \\
\hline
\end{tabular}


3.4.2. Determination of Minimal Inhibitory Concentration (MIC) and Fungicidal Concentration (MFC) of Thyme Essential Oil (TEO)

The inhibitory potential of TEO was further assessed by determining its MIC and MFC against all isolates of $C$. albicans (Table 5). A strong antifungal activity was recorded by the treatment of oil against $C$. albicans where 17 out of 20 isolates showed MIC as low as $0.6 \mu \mathrm{L} / \mathrm{mL}$. At this concentration $(0.6 \mu \mathrm{L} / \mathrm{mL})$, the fungal growth was completely inhibited. The TEO were slightly lesser effective against isolates no. 4, 8, and 9. The fungicidal effect of TEO was also evaluated by determining the MFC. The MFCs was taken as the lowest concentration of TEO completely inhibiting the growth of $C$. albicans with fewer than 3 colonies of SDA plates. The presence of $1.25 \mu \mathrm{L} / \mathrm{mL}$ in culture medium was fungicidal to all strains of $C$. albicans isolated from blood. Most strains of $C$. albicans vaginal isolate showed MFC as $1.25 \mu \mathrm{L} / \mathrm{mL}$. However, the TEO were fungistatic at higher concentration for 3 isolates (no. 4, 8, and 9).

Table 5. Minimal Inhibitory Concentration (MIC) and Fungicidal Concentration (MFC) of the Thyme essential oil (TEO) against C. albicans.

\begin{tabular}{ccccc}
\hline \multirow{2}{*}{ Isolates } & \multicolumn{2}{c}{ MIC } & \multicolumn{2}{c}{ MFC } \\
\cline { 2 - 5 } & Thyme & Fluconazole & Thyme & Fluconazole \\
\hline 1 & 0.6 & 0 & 1.25 & 0 \\
2 & 0.6 & 0 & 1.25 & 0 \\
3 & 0.6 & 0 & 1.25 & 0 \\
4 & 1.25 & 0 & 2.5 & 0 \\
5 & 0.6 & 0 & 1.25 & 0 \\
6 & 0.6 & 0 & 1.25 & 0 \\
7 & 0.6 & 0 & 1.25 & 128 \\
8 & 1.25 & 64 & 2.5 & 0 \\
9 & 1.25 & 0 & 2.5 & 128 \\
10 & 0.6 & 64 & 1.25 & 0 \\
11 & 0.6 & 04 & 1.25 & 0 \\
12 & 0.6 & 0 & 1.25 & 0 \\
13 & 0.6 & 0 & 1.25 & 0 \\
14 & 0.6 & 0 & 1.25 & 0 \\
15 & 0.6 & 0 & 1.25 & 128 \\
16 & 0.6 & 0 & 1.25 & 0 \\
17 & 0.6 & 32 & 1.25 & 0 \\
18 & 0.6 & 0 & 1.25 & 1.25 \\
19 & 0.6 & 32 & 1.25 & \\
20 & 0.6 & 0 & &
\end{tabular}

The sign " 0 " represents resistance to fluconazole.

\subsubsection{Effect of TEO on Budding of C. albicans}

The effect of TEO used in this study on the budding of $C$. albicans isolates was also investigated and the results are represented in Figure 5. Results show that the TEO was more effective in inhibiting the bud formation compared to the positive control (i.e., fluconazole). The TEO interfered with the budding rate of all tested C. albicans isolates. The budding rate against all tested C. albicans isolates ranged from $13.9 \%$ to $29.7 \%$. TEO was most effective against isolate no. 13 where only $13.9 \%$ budding was recorded. The lowest budding rate was observed in isolate no. 1. The budding rate in the presence of fluconazole ranged from $31.6 \%$ to $89.2 \%$. Overall, the TEO was found to be effective in preventing the budding of all tested C. albicans isolates both from vagina and blood. 


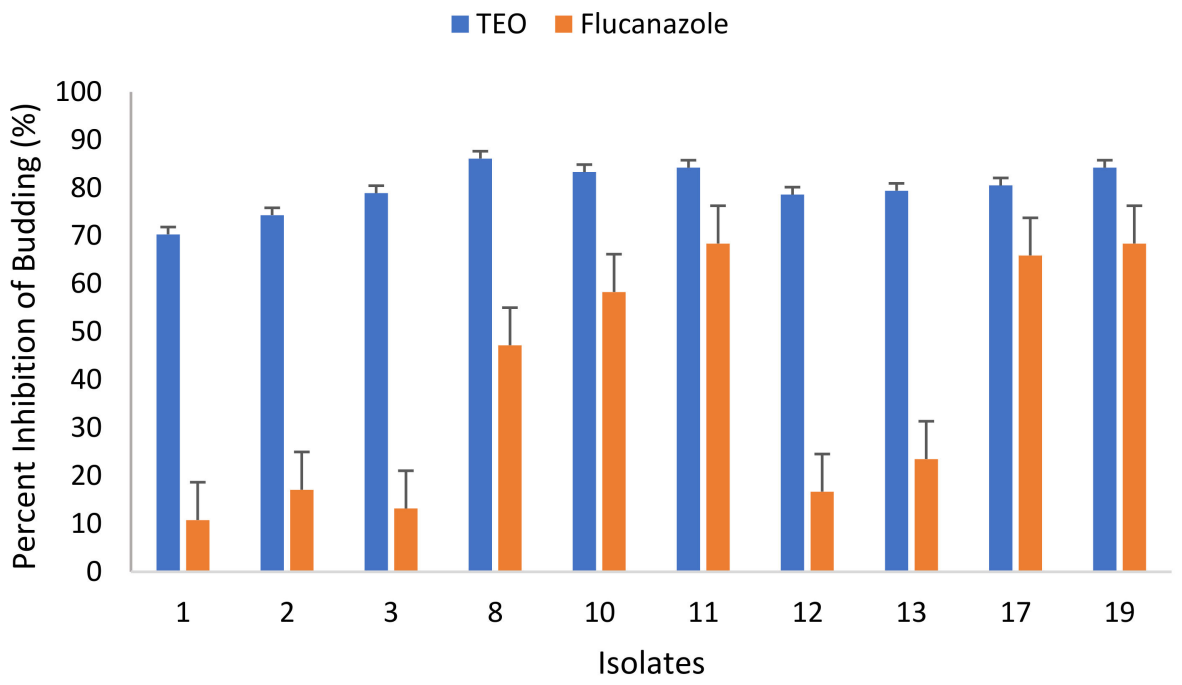

Figure 5. Percent inhibition of budding formation of C. albicans incubated at sub-inhibitory concentrations $(1 / 2 \times \mathrm{MIC})$ of the Thyme essential oil (TEO).

\subsubsection{Effect of TEO on Germ Tubes Formation of C. albicans Isolates}

The effect of TEO in inhibiting the germ tube formation in C. albicans was also evaluated (Figure 6). The TEO was able to reduce the formation of germ tubes in all tested $C$. albicans isolates. For instance, the germ tube development in isolates no. 1 and 2 was found to be $13.0 \%$ and $5.9 \%$, respectively. The germ tube formation in blood isolates of $C$. albicans were also reduced and only $7.1 \%$ and $16.7 \%$ germ tube formation in no. 11 and 12 was recorded. The results clearly show that germ tube formation was strongly inhibited by thyme oil at $1 / 2 \times$ MIC. Moreover, the TEO were found to be effective in reducing the germ tube development of all tested C. albicans isolates, both from vagina and blood.

- TEO Flucanazole

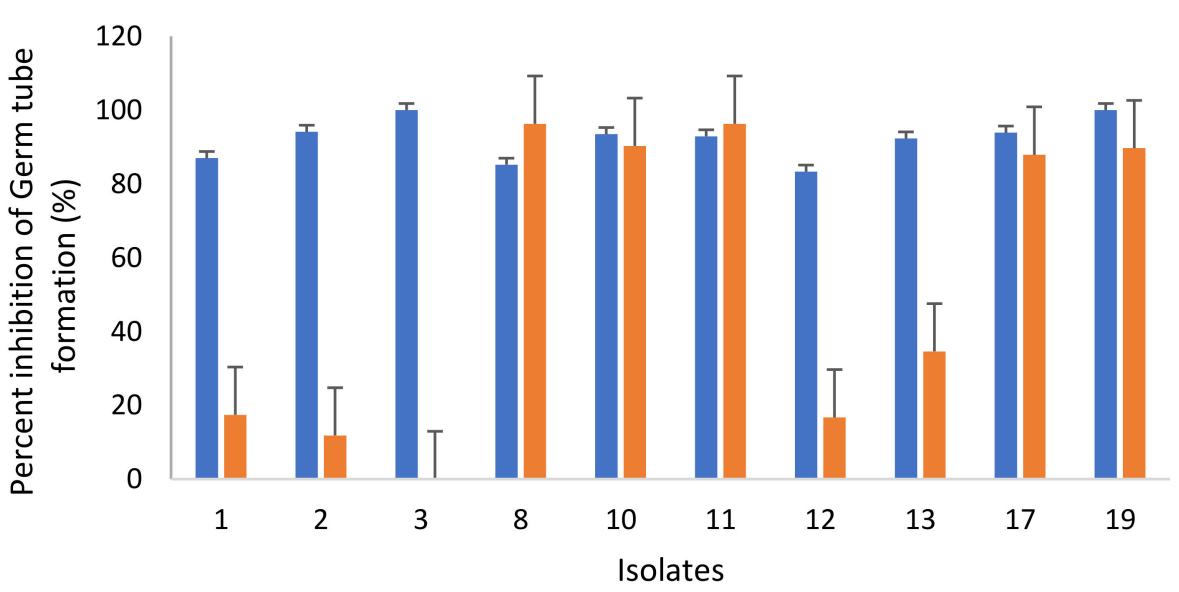

Figure 6. Percent inhibition of germ tube formation of C. albicans incubated at sub-inhibitory concentrations $(1 / 2 \times \mathrm{MIC})$ of the Thyme essential oil (TEO).

\subsubsection{Time-Kill Curves of C. albicans Isolates}

The fungicidal potential of TEO was examined using time kill assays. The findings showed that an excellent fungicidal effect was found at the respective MFCs. The $C$. albicans isolates were highly susceptible to tested oil at this concertation. The number of colonies for germinated cells was strongly reduced in all C. albicans isolates after $12 \mathrm{~h}$ of incubation. The complete fungicidal effect was observed at $18 \mathrm{~h}$ of incubation. For comparison, the fluconazole-resistant $C$. albicans isolates no. 8, 10,11, 17 were also tested with fluconazole. The TEO were more effective than the fluconazole at lower doses (Figure 7). The C. albicans 
isolates treated with fluconazole showed regrowth from $18-24 \mathrm{~h}$ in isolates no. 8 and 10, which was not observed in presence of essential oil.

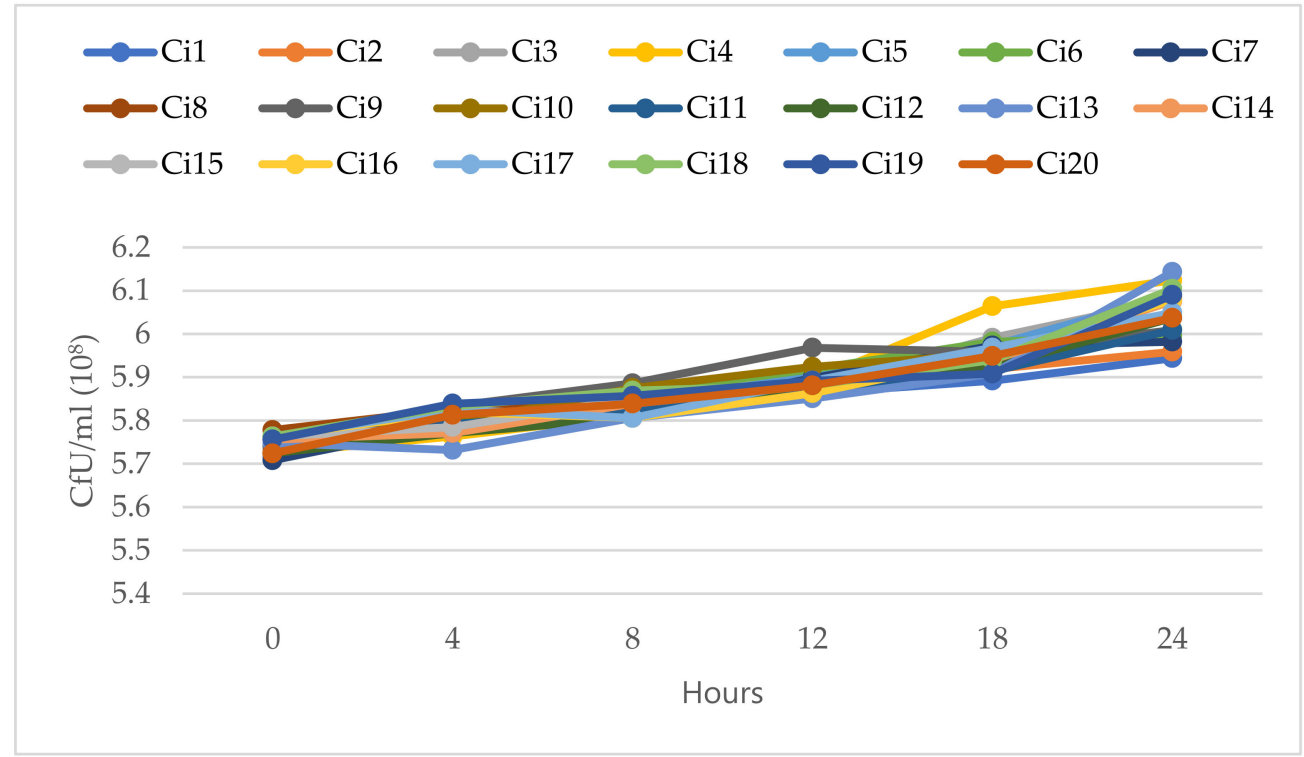

(a)

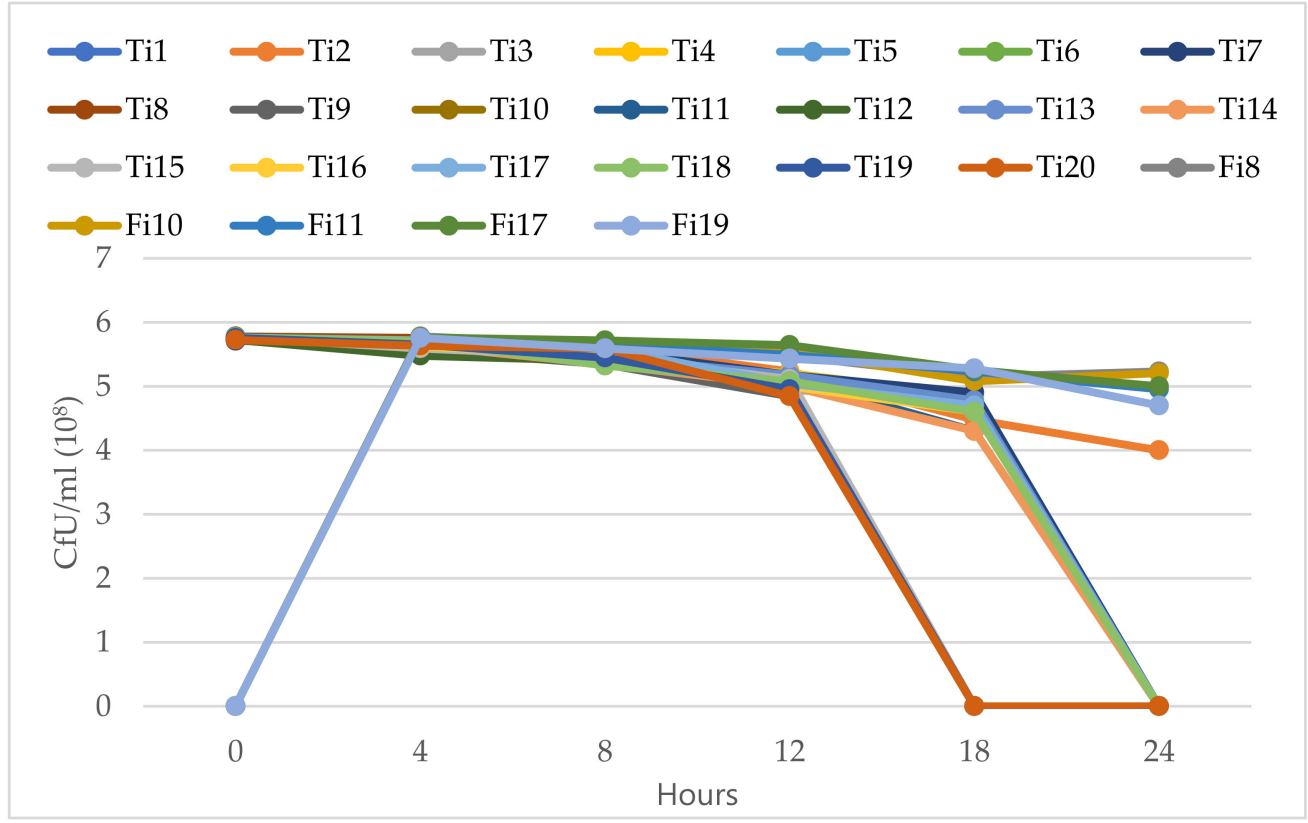

(b)

Figure 7. Time-kill of $C$. albicans on different times $(0-24 \mathrm{~h})$ : (a) untreated (Control) isolates of C. albicans (Ci1-Ci20); (b) C. albicans isolates (Ti1-Ti20) treated with Minimum fungicidal concentration (MFC) dose of thyme essential oil (TEO) and C. albicans susceptible isolates (Fi8, Fi10, 1Fi1, Fi17, Fi19) treated with Fluconazole.

3.4.6. Effect of TEO on the C. albicans Ultrastructure Detected by Scanning Electron Microscopy (SEM)

In order to investigate the effect of the TEO on the ultrastructure of C. albicans, samples were examined by scanning electron microscopy (SEM). SEM analyses showed that untreated cells (control) exhibited a normal budding profile and had a typical structure with smooth wall (Figure 8A). Cells treated with TEO showed bumps and holes on the cell wall, which was not observed in control cells (Figure 8B). 



Figure 8. (A) Scanning electron micrographs showing C. albicans biofilm after $24 \mathrm{~h}$ without treatment at (i) $2000 \times$, (ii) $5000 \times$, and (iii) $25,000 \times$. (B) Scanning electron micrographs showing effects on C. albicans biofilm after $24 \mathrm{~h}$ treatment with TEO at (i) $2000 \times$ (ii) $10,000 \times$, and (iii) $25,000 \times$.

\section{Discussion}

The Candida spp. infections have become common in hospitalized patients and their emergence is favored by immunosuppression. The C. albicans isolates were identified and characterized by employing several assays. The results prove that the most prevalent species in the collected samples were $C$. albicans. CHROMagar is differential culture medium which is routinely used for identification of clinical species of yeast. On this fungal culture medium, C. albicans produces distinctive green colonies, C. glabrata gives pink to purple colonies, $C$. tropicalis shows steel blue colonies, $C$. krusei shows rose coloured colonies with white edges [31-33]. Our findings corroborate an earlier report in which C. albicans was found to be the most common isolated species that caused candidemia at the Armed Forces Hospital, Riyadh, with 50.7\% cases [1]. Moreover, it is also reported by several authors that the most frequently encountered species in Candida infections is C. albicans $[32,34,35]$.

It has been noted that $C$. albicans fungemia is common in individuals suffering from respiratory infections or premature infants. On the other hand, patients with hepatic disorders or leukemia are vulnerable to $C$. tropicalis [36]. The clinical isolates of $C$. albicans formed germ tubes in horse serum when incubated at $37^{\circ} \mathrm{C}$. The formation of germ tubes within $2 \mathrm{~h}$ of incubation is the unique diagnostic characteristic of $C$. albicans that differentiates it from other fungi. As documented, up to $5 \%$ of $C$. albicans strains do not produce germ tube [37]. Usually, other yeasts do not form germ tubes within $3 \mathrm{~h}$, neither 
C. glabrata nor C. tropicalis, although there are discrepancies as to which medium is best for germ tube production. For instance, some reports say that human serum is the best for the germ tube test $[38,39]$. However, other finding has suggested that trypticase soy broth is a better medium for testing germ tube production of C. albicans than human serum and horse serum [40]. Some studies that compared the performance of current chromogenic yeast identification have found that API 20C Aux was better than the other tests [24,41].

C. albicans is a pathogen that is primarily involved with systemic and superficial infections, affecting mainly chronic and immunocompromised patients; moreover, infection rates are rising as the number of such pateints rise [42]. The main advantage of RAPDPCR over other methods of identification is that this technique is relatively faster and only takes a small amount of DNA. We intended to check whether these distinct primers could successfully amplify the DNA of isolates of C. albicans. The RSD-11 based genotypic differentiation of the isolates revealed the presence of four different genotypes in 20 Candida isolates. OPG-17, on the other hand, has the same genotype profile as the Candida. Our results deviate from a previous study that recorded four distinct genotypes in 14 Candida isolates when using OPG-17, whereas the same genotype profile was found with OPG14 [43]. The pathogenicity of these isolates is probably owing to their genotypic features or because of the favorable growth environment they have within their hosts. The genotyping of Candida strains using PCR depends on the choice of primers [44]. The primers (OPG-17 and RSD-11) used in this work may be able to detect genomic variability among C. albicans isolates. Overall, the RAPD results showed that most patients exhibited varying and disparate genotypic patterns either within the same or different individuals.

In many countries, certain infectious diseases, including those caused by drug resistant pathogenic fungi, are treated with traditionally used herbal remedies. This had led the researcher to screen and search the potential new compounds for antifungal activities from natural sources, especially from ethnopharmacologically used plants. Owing to the toxicity of essential nature of oil, interests in essential oil with antifungal properties have increased. The essential oil yielded from the aerial part of T. vulgaris contains a high amount of thymol. The findings are in agreement with the earlier report which showed that thymol was a major component of thyme with a percentage ranging from 40-70\% [45-49]. However, a high percentage of thymol is also reported in which thymol $(84.45 \%)$ and carvacrol $(46.62 \%)$ were the main components of T. daenensis and T. vulgaris, respectively [50]. Another finding has documented that a total of 33 compounds were identified in which thymol, cymol, $\gamma$-terpinene, caryophyllene, and $\alpha$-terpinene were the major components in T. vulgaris [51]. Similarly, another study has found thymol $(33.14 \%)$, carvacrol $(19.59 \%)$, and linalool $(16.00 \%)$ as the major components of thyme [52]. Variations in chemical composition of essential oils may be attributable to the various abiotic factors, geographic conditions, plant stage at the time of collection [53]. Despite the fact that essential oils' antibacterial activity is mostly owing to their main components, the synergistic or antagonistic impact of a single chemical component in a small fraction of the essential oil composition has to be taken into account [9].

The antifungal activity of essential oils of natural origin is mainly owed to the bioactive phytocompounds that may be either acting individually or in synergy with other compounds [9]. Our results are in agreement with other studies where a remarkable antifungal activity of Thymus oil was found against $C$. albicans [54-56]. It is documented that thyme essential oil (TEO) exhibits strong antifungal activity on the growth of $C$. albicans with an inhibition zone of $56 \pm 1.5 \mathrm{~mm}$ [56]. Similarly, another finding has reported that the thyme oil was strongly fungistatic against $C$. albicans with zone of inhibition at $35 \mathrm{~mm}$ [57]. Moreover, essential oil obtained from $T$. daenensis was also found to produce good antifungal activity against $C$. albicans [50]. On the contrary, essential oil of thyme has also been found to exhibit weak antifungal activity against C. albicans isolates [58]. The variation in antifungal activity of essential oil of thyme not only depends on the strains of yeast tested, but also on the phytochemical composition of the plant which varies with the environment, season, and geographical locations. The GC/MS analysis revealed that thymol (73.1\%) and $\gamma$-terpinene 
$(9.9 \%)$ were the major components. Based on the available literature, it is inferred that the antifungal activity of essential oil mainly was due to the presence of thymol, carvacrol, and linalool $[59,60]$.

At very low doses, the TEO proved to be fungistatic and fungicidal. This result is in concordance with a previous study which reported that thyme has the highest inhibitory activity against $C$. albicans [61]. Nevertheless, it is reasonable to speculate that the activity of TEO is owed to the presence of thymol and carvacrol since these compounds were detected in GC/MS. The relevance of phenolic hydroxyl groups for antimicrobial action has already been described [62-64]. Thymus species have been reported to be rich in phenol content and to have antifungal activity against several pathogenic fungi, including fluconazole resistant isolates $[8,65,66]$. Further, TEO was successful in inhibiting the bud formation. The result corroborates other studies which showed the reduction in bud formation of C. albicans by O. gratissimum essential oil. The probable reason for the lower budding rate may be the deleterious effect of the TEO on the pathogen's cell wall, noting that the cell wall coherence is a key element in cell division [67]. Moreover, the TEO was found to be effective in reducing the germ tube development of all tested $C$. albicans isolates, both from vagina and blood. A similar finding has been reported earlier in which thymus oil significantly inhibited the germ tubes formation [66].

Overall, the TEO was found to be a more effective fungicide than fluconazole. This result is comparable with previous study that reported the Candida species treated with antifungal (nystatin) showed regrowth from 24-48 h, which was not observed with used TEO [67]. Moreover, the results are in concordance with another report which found that C. albicans was more susceptible to oregano oil and fungicidal effect was observed within $24 \mathrm{~h}$ [68]. It has been reported that linalool and eugenol killed 99.9\% inoculums of C. albicans within 7.5 min [69]. Therefore, the killing of fungi by the active constituents may be attributed to fungicidal effects of the of essential oil.

SEM analysis further confirmed the damage caused by TEO to C. albicans. A similar result was reported earlier in which deformed cells with areas that resembled frustrated budding sites were observed in treated C. albicans with O. gratissimum (basil) oil [67]. Moreover, another study reported cells of C. albicans treated with oregano oil showed notable alterations in the cell wall [68]. A similar observation was also found using atomic force microscopy (AFM) where C. albicans cells showed major structural deformities at increasing thymol concentrations. A number of flattened cells with surface folds, cells with holes, and collapsed cells and ghosts were also seen [70]. Terpenes have been shown to modify the fluidity of the cell membrane, which affects permeability. This causes cell surface changes and abnormalities, which influence the pathogen's adhesion and virulence. Thymol is an amphipathic monoterpene; therefore, it may have affected the cell membrane structure by generating imbalances and stresses in the cell membrane. Another study reported that thymol were more potent than eugenol in terms of its ability to interfere with the architecture of the C. albicans envelope [71].

\section{Conclusions}

Due to the global emergence and spread of antimicrobial resistance both in bacterial and fungal pathogens, the management of infectious diseases has become a daunting task. To overcome this problem, a lot of new strategies are being explored. One such strategy is to test the traditionally used medicinal plants, particularly essential oil, against the fungal pathogens. The phytochemical analysis revealed that thymol was the major component of hydro-distilled essential oil. Thyme essential oil (TEO) effectively inhibited the growth of $C$. albicans isolates. Moreover, the TEO was fungistatic and fungicidal at very low concentrations. The oil was also more potent in killing the fungal pathogens than fluconazole. This study provides experimental evidence for antifungal activity of essential of thyme that may be explored for the development of novel therapeutic agent, especially for the infection caused by C. albicans. 
Author Contributions: N.A.A. methodology, investigation, writing-original draft; K.P. conceptualization, writing-review and editing, supervision. All authors have read and agreed to the published version of the manuscript.

Funding: This research received no external funding.

Institutional Review Board Statement: Not applicable.

Informed Consent Statement: Not applicable.

Data Availability Statement: The data presented in this study are available in the article.

Acknowledgments: The authors would like to acknowledge the support provided by Researchers Supporting Project Number (RSP-2021/358), King Saud University, Riyadh, Saudi Arabia.

Conflicts of Interest: The authors declare no conflict of interest.

\section{References}

1. Al-Jasser, A.M.; Elkhizzi, N.A. Distribution of Candida species among bloodstream isolates. Saudi Med. J. 2004, 25, 566-569.

2. Badhman, H. Variation in Growth of Candida albicans in Different Media. Ph.D. Thesis, King Abdul-Aziz University, Jeddah, Saudi Arabia, 2006.

3. Edwards, J. Candida species. In Principles and Practice of Infectious Diseases; Mandell, G.L., Douglas, R.G., Bennett, J.E., Eds.; Churchill Livingstone: New York, NY, USA, 1995; pp. 2289-2301.

4. Douglas, L.J. Candida biofilms and their role in infection. Trends Microbiol. 2003, 11, 30-36. [CrossRef]

5. Eggimann, P.; Garbino, J.; Pittet, D. Management of candidiasis Management of Candida species infections in critically ill patients. Lancet Infect. Dis. 2003, 3, 772-785. [CrossRef]

6. Al-Hedaithy, S. Spectrum and proteinase production of yeasts causing vaginitis in Saudi Arabian women. Med. Sci. Monit. 2002, 8, CR498-CR501.

7. Kalemba, D.; Kunicka, A. Antibacterial and Antifungal Properties of Essential Oils. Curr. Med. Chem. 2003, 10, 813-829. [CrossRef] [PubMed]

8. Dorman, H.J.D.; Deans, S.G. Antimicrobial agents from plants: Antibacterial activity of plant volatile oils. J. Appl. Microbiol. 2000, 88, 308-316. [CrossRef] [PubMed]

9. Burt, S. Essential oils: Their antibacterial properties and potential applications in foods-A review. Int. J. Food Microbiol. 2004, 94, 223-253. [CrossRef]

10. Bakkali, F.; Averbeck, S.; Averbeck, D.; Idaomar, M. Biological effects of essential oils—A review. Food Chem. Toxicol. 2008, 46, 446-475. [CrossRef] [PubMed]

11. Khan, A.; Ahmad, A.; Manzoor, N.; Khan, L.A. Antifungal Activities of Ocimum sanctum Essential Oil and its Lead Molecules. Nat. Prod. Commun. 2010, 5, 1934578X1000500. [CrossRef]

12. Ahmad, A.; Khan, A.; Manzoor, N.; Khan, L.A. Evolution of ergosterol biosynthesis inhibitors as fungicidal against Candida. Microb. Pathog. 2010, 48, 35-41. [CrossRef]

13. Pinto, E.; Pina-Vaz, C.; Salgueiro, L.; Gonçalves, M.J.; de-Oliveira, C.S.; Cavaleiro, C.; Palmeira, A.; Rodrigues, A.; de-Oliveira, M.J. Antifungal activity of the essential oil of Thymus pulegioides on Candida, Aspergillus and dermatophyte species. J. Med. Microbiol. 2006, 55, 1367-1373. [CrossRef] [PubMed]

14. Azzouz, M.; Bullerman, L. Comparative Antimycotic Effects of Selected Herbs, Spices, Plant Components and Commercial Antifungal Agents1. J. Food Prot. 1982, 45, 1298-1301. [CrossRef]

15. Knobloch, K.; Pauli, A.; Iberl, B.; Weigand, H.; Weis, N. Antibacterial and Antifungal Properties of Essential Oil Components. J. Essent. Oil Res. 1989, 1, 119-128. [CrossRef]

16. Ahmad, I.; Qais, F.; Samreen; Abulreesh, H.; Ahmad, S.; Rumbaugh, K. Antibacterial Drug Discovery: Perspective Insights. In Antibacterial Drug Discovery to Combat MDR; Springer: Singapore, 2019; pp. 1-21.

17. Edeoga, H.O.; Okwu, D.E.; Mbaebie, B.O. Phytochemical constituents of some Nigerian medicinal plants. Afr. J. Biotechnol. 2005, 4, 685-688. [CrossRef]

18. Barreca, S.; La Bella, S.; Maggio, A.; Licata, M.; Buscemi, S.; Leto, C.; Pace, A.; Tuttolomondo, T. Flavouring Extra-Virgin Olive Oil with Aromatic and Medicinal Plants Essential Oils Stabilizes Oleic Acid Composition during Photo-Oxidative Stress. Agriculture 2021, 11, 266. [CrossRef]

19. Salehi, B.; Mishra, A.P.; Shukla, I.; Sharifi-Rad, M.; del Contreras, M.M.; Segura-Carretero, A.; Fathi, H.; Nasrabadi, N.N.; Kobarfard, F.; Sharifi-Rad, J. Thymol, thyme, and other plant sources: Health and potential uses. Phyther. Res. 2018, 32, 1688-1706. [CrossRef]

20. Sharifi-Rad, M.; Varoni, E.M.; Iriti, M.; Martorell, M.; Setzer, W.N.; del Mar Contreras, M.; Salehi, B.; Soltani-Nejad, A.; Rajabi, S.; Tajbakhsh, M.; et al. Carvacrol and human health: A comprehensive review. Phyther. Res. 2018, 32, 1675-1687. [CrossRef]

21. Kowalczyk, A.; Przychodna, M.; Sopata, S.; Bodalska, A.; Fecka, I. Thymol and thyme essential oil-New insights into selected therapeutic applications. Molecules 2020, 25, 4125. [CrossRef] 
22. Nadeem, S.G.; Hakim, S.T.; Kazmi, S.U. Use of CHROMagar Candida for the presumptive identification of Candida species directly from clinical specimens in resource-limited settings. Libyan J. Med. 2010, 5, 2144. [CrossRef]

23. Sheppard, D.C.; Locas, M.-C.; Restieri, C.; Laverdiere, M. Utility of the Germ Tube Test for Direct Identification of Candida albicans from Positive Blood Culture Bottles. J. Clin. Microbiol. 2008, 46, 3508-3509. [CrossRef] [PubMed]

24. Gundes, S.; Gulenc, S.; Bingol, R. Comparative performance of Fungichrom I, Candifast and API 20C Aux systems in the identification of clinically significant yeasts. J. Med. Microbiol. 2001, 50, 1105-1110. [CrossRef]

25. Scherer, S.; Stevens, D. Application of DNA typing methods to epidemiology and taxonomy of Candida species. J. Clin. Microbiol. 1987, 25, 675-679. [CrossRef]

26. Abed, K.M.; Naife, T.M. Extraction of Essential Oil from Iraqi Eucalyptus Camadulensis Leaves by Water Distillation Methods. IOP Conf. Ser. Mater. Sci. Eng. 2018, 454, 012163. [CrossRef]

27. Khan, M.S.A.; Malik, A.; Ahmad, I. Anti-candidal activity of essential oils alone and in combination with amphotericin B or fluconazole against multi-drug resistant isolates of Candida albicans. Med. Mycol. 2012, 50, 33-42. [CrossRef] [PubMed]

28. Jafri, H.; Banerjee, G.; Khan, M.S.A.; Ahmad, I.; Abulreesh, H.H.; Althubiani, A.S. Synergistic interaction of eugenol and antimicrobial drugs in eradication of single and mixed biofilms of Candida albicans and Streptococcus mutans. AMB Express 2020, 10, 185. [CrossRef]

29. Jafri, H.; Ahmad, I. Thymus vulgaris essential oil and thymol inhibit biofilms and interact synergistically with antifungal drugs against drug resistant strains of Candida albicans and Candida tropicalis. J. Mycol. Med. 2020, 30, 100911. [CrossRef] [PubMed]

30. Alshaikh, N.; Perveen, K. Anti-candidal Activity and Chemical Composition of Essential Oil of Clove (Syzygium aromaticum). J. Essent. Oil Bear. Plants 2017, 20, 951-958. [CrossRef]

31. Odds, F.; Bernaerts, R. CHROMagar Candida, a new differential isolation medium for presumptive identification of clinically important Candida species. J. Clin. Microbiol. 1994, 32, 1923-1929. [CrossRef]

32. Yucesoy, M.; Marol, S. Performance of CHROMAgar and BIGGY agar for identification of yeast species. Ann. Clin. Microbiol. Antimicrob. 2003, 2, 8. [CrossRef] [PubMed]

33. Sivakumar, V.G.; Shankar, P.; Nalina, K.; Menon, T. Use of CHROMagar in the Differentiation of Common Species of Candida. Mycopathologia 2009, 167, 47-49. [CrossRef]

34. Yera, H.; Poulain, D.; Lefebvre, A.; Camus, D.; Sendid, B. Polymicrobial candidaemia revealed by peripheral blood smear and chromogenic medium. J. Clin. Pathol. 2004, 57, 196-198. [CrossRef] [PubMed]

35. Linares, M.J.; Charriel, G.; Solís, F.; Casal, M. CHROMAgar Candida with fluconazole: Comparison with microdilution techniques. Enferm. Infecc. Microbiol. Clin. 2003, 21, 493-497. [CrossRef] [PubMed]

36. AlHedaithy, S. The yeast species causing fungemia at a university hospital in Riyadh, Saudi Arabia, during a 10-year period. Das Hefespektrum der Fungamien an einem Universitatshospital in Riad, Saudi-Arabien, wahrend einer Zehnjahresperiode. Mycoses 2003, 46, 275-280. [CrossRef] [PubMed]

37. Salkin, I.; Land, G.; Hurd, N.; Goldson, P.; McGinnis, M. Evaluation of Yeast- Ident and Uni-Yeast-tek yeast identification systems. J. Clin. Microbiol. 1987, 25, 624-627. [CrossRef]

38. Makwana, G.; Gadhavi, H.; Sinha, M. Comparison of germ tube production by Candida albicans in various media. NJIRM 2012, 3, 6-8.

39. Arora, D.R.; Saini, S.; Aparna; Gupta, N. Evaluation of germ tube test in various media. Indian J. Pathol. Microbiol. 2003, $46,124-126$.

40. Deorukhkar, S.; Saini, S.; Jadhav, P. Evaluation of different media for germ tube production of Candida albicans and Candida dubliniensis. IJBAR 2012, 3, 704-707. [CrossRef]

41. Schuffenecker, I.; Freydière, A.; Montclos, H.; Gille, Y. Evaluation of four commercial systems for identification of medically important yeasts. Eur. J. Clin. Microbiol. Infect. Dis. 1993, 12, 255-260. [CrossRef]

42. Anwar, K.P.; Malik, A.; Subhan, K.H. Profile of candidiasis in HIV infected patients. Iran. J. Microbiol. 2012, 4, $204-209$.

43. Costa, C.; Silva, M.; Souza, L.; ElAssal, F.; Ataíde, F.; Paula, C. RAPD profile among Candida albicans isolates by using different primers. Rev. Patol. Trop. 2010, 39, 41-47.

44. Dassanayake, R.; Samaranayake, L. Characterization of the genetic diversity in superficial and systemic human isolates of Candida parapsilosis by randomly amplified polymorphic DNA (RAPD). APMIS 2000, 108, 153-160. [CrossRef]

45. Khan, A.A.; Amjad, M.S. Saboon GC-MS analysis and biological activities of Thymus vulgaris and Mentha arvensis essential oil. Turk. J. Biochem. 2019, 44, 388-396. [CrossRef]

46. Sefidkon, F.; Jamzad, Z. Chemical composition of the essential oil of three Iranian Satureja species (S. mutica, S. macrantha and S. intermedia). Food Chem. 2005, 91, 1-4. [CrossRef]

47. Móricz, Á.; Ott, P.; Böszörményi, A.; Lemberkovics, É.; Mincsovics, E.; Tyihák, E. Bioassay-Guided Isolation and Identification of Antimicrobial Compounds from Thyme Essential Oil by Means of Overpressured Layer Chromatography, Bioautography and GC-MS. Chromatographia 2012, 75, 991-999. [CrossRef]

48. Moghtader, M. Antifungal effects of the essential oil from Thymus vulgaris L. and comparison with synthetic thymol on Aspergillus niger. J. Yeast Fungal Res. 2012, 3, 83-88. [CrossRef]

49. Negahban, M.; Saeedfar, S. Essential Oil Composition of Thymus vulgaris L. Russ. J. Biol. Res. 2015, 3, 35-38. [CrossRef]

50. Behbahani, M.; Ghasemi, Y.; Khoshnoud, M.; Faridi, P.; Moradli, G.; Najafabady, N. Volatile oil composition and antimicrobial activity of two Thymus species. Pharmacogn. J. 2013, 5, 77-79. [CrossRef] 
51. Calín-Sánchez, Á.; Figiel, A.; Lech, K.; Szumny, A.; Carbonell-Barrachina, Á.A. Effects of Drying Methods on the Composition of Thyme (Thymus vulgaris L.) Essential Oil. Dry. Technol. 2013, 31, 224-235. [CrossRef]

52. Omidbeygi, M.; Barzegar, M.; Hamidi, Z.; Naghdibadi, H. Antifungal activity of thyme, summer savory and clove essential oils against Aspergillus flavus in liquid medium and tomato paste. Food Control 2007, 18, 1518-1523. [CrossRef]

53. Gad, H.A.; Ayoub, I.M.; Wink, M. Phytochemical profiling and seasonal variation of essential oils of three Callistemon species cultivated in Egypt. PLoS ONE 2019, 14, e0219571. [CrossRef]

54. Pavel, M.; Alecu, F. Antifungal activity of Thymus serpyllum essential oil against Candida albicans and Candida non-albicans clinical isolates: R2458. Clin. Microbiol. Infect. 2008, 14, 19-22.

55. Naeini, A.; Khosravi, A.R.; Chitsaz, M.; Shokri, H.; Kamlnejad, M. Anti- Candida albicans activity of some Iranian plants used in traditional medicine. J. Mycol. Med. 2009, 19, 168-172. [CrossRef]

56. Omran, S.; Esmailzadeh, S. Comparison of anti-Candida activity of thyme, pennyroyal, and lemon essential oils versus antifungal drugs against Candida species. Jundishapur J. Microbiol. 2009, 2, 53-60.

57. Ownagh, A.; Majdani, R.; Yaghobzadeh, N.; Nemati, Z. Antifungal effects of Thyme oil on Candida albicans and Aspergillus fumigates. Iran. J. Vet. Med. 2008, 22, 1-7.

58. Dalirsani, Z.; Adibpour, M.; Aghazadeh, M.; Amirchaghmaghi, M.; Mozafari, P.; Hamzei, F. In vitro comparison of inhibitory activity of 10 plant extracts against Candida albicans. Aust. J. Basic Appl. Sci. 2011, 5, 930-935.

59. Sivropoulou, A.; Papanikolaou, E.; Nikolaou, C.; Kokkini, S.; Lanaras, T.; Arsenakis, M. Antimicrobial and Cytotoxic Activities of Origanum Essential Oils. J. Agric. Food Chem. 1996, 44, 1202-1205. [CrossRef]

60. Rota, C.; Carraminana, J.; Burillo, J.; Herrera, A. In Vitro Antimicrobial Activity of Essential Oils from Aromatic Plants against Selected Foodborne Pathogens. J. Food Prot. 2004, 67, 1252-1256. [CrossRef]

61. Omran, S.; Esmaeilzadeh, S.; Rahmani, Z. Laboratory study of anticandidal activity of thyme, pennyroyal and lemon essential oils by micro dilution method. Jundishapur J. Microbiol. 2010, 3, 161-167.

62. Adam, K.; Sivropoulou, A.; Kokkini, S.; Lanaras, T.; Arsenakis, M. Antifungal Activities of Origanum vulgare subsp. hirtum, Mentha spicata, Lavandula angustifolia, and Salvia fruticosa Essential Oils against Human Pathogenic Fungi. J. Agric. Food Chem. 1998, 46, 1739-1745. [CrossRef]

63. Aligiannis, N.; Kalpoutzakis, E.; Mitaku, S.; Chinou, I.B. Composition and Antimicrobial Activity of the Essential Oils of Two Origanum Species. J. Agric. Food Chem. 2001, 49, 4168-4170. [CrossRef]

64. Nostro, A.; Blanco, A.R.; Cannatelli, M.A.; Enea, V.; Flamini, G.; Morelli, I.; Roccaro, S.A.; Alonzo, V. Susceptibility of methicillinresistant staphylococci to oregano essential oil, carvacrol and thymol. FEMS Microbiol. Lett. 2004, 230, 191-195. [CrossRef]

65. Nguefack, J.; Leth, V.; Zollo, A.P.H.; Mathur, S.B. Evaluation of five essential oils from aromatic plants of Cameroon for controlling food spoilage and mycotoxin producing fungi. Int. J. Food Microbiol. 2004, 94, 329-334. [CrossRef] [PubMed]

66. Pina-Vaz, C.; Rodrigues, G.A.; Pinto, E.; de-Oliveira, C.S.; Tavares, C.; Salgueiro, L.; Cavaleiro, C.; Goncalves, M.; de-Oliveira, M.J. Antifungal activity of Thymus oils and their major compounds. J. Eur. Acad. Dermatol. Venereol. 2004, 18, 73-78. [CrossRef] [PubMed]

67. Ueda-Nakamura, T.; Mendonça-Filho, R.R.; Morgado-Díaz, J.A.; Maza, K.P.; Filho, B.P.D.; Cortez, A.G.D.; Alviano, D.S.; do Rosa, M.S.S.; Lopes, A.H.C.S.; Alviano, C.S.; et al. Antileishmanial activity of Eugenol-rich essential oil from Ocimum gratissimum. Parasitol. Int. 2006, 55, 99-105. [CrossRef]

68. Makki, S.; Olama, Z.; Holail, H. Anti-fungal activity of plant oils against oral clinical isolates of Candida albicans in Lebanese community. Topclass J. Microbiol. 2012, 1, 42-54.

69. Zore, G.B.; Thakre, A.D.; Jadhav, S.; Karuppayil, S.M. Terpenoids inhibit Candida albicans growth by affecting membrane integrity and arrest of cell cycle. Phytomedicine 2011, 18, 1181-1190. [CrossRef] [PubMed]

70. Braga, P.C.; Ricci, D. Thymol-Induced Alterations in Candida albicans Imaged by Atomic Force Microscopy. In Atomic Force Microscopy in Biomedical Research; Springer: Berlin/Heidelberg, Germany, 2011; pp. 401-410.

71. Braga, P.; Sasso, M.; Culici, M.; Alfieri, M. Eugenol and thymol, alone or in combination, induce morphological alterations in the envelope of Candida albicans. Fitoterapia 2007, 78, 396-400. [CrossRef] 